\title{
Shadow Banking and the Commercial Bank Loan Loss Provisions
}

\author{
Quanfeng Qiu \\ School of Management, Jinan University, Guangzhou, China \\ Email:15768181541@163.com
}

How to cite this paper: Qiu, Q.F. (2020) Shadow Banking and the Commercial Bank Loan Loss Provisions. Modern Economy, $11,155-164$.

https://doi.org/10.4236/me.2020.111014

Received: December 13, 2019

Accepted: January 14, 2020

Published: January 17, 2020

Copyright () 2020 by author(s) and Scientific Research Publishing Inc. This work is licensed under the Creative Commons Attribution International License (CC BY 4.0).

http://creativecommons.org/licenses/by/4.0/

\begin{abstract}
This article uses 2008-2018 data from China's commercial banks to analyze the impact of shadow banking on banks' loan loss provisions. The results of this study show that shadow banking is significantly positively correlated with the loan loss provisions for commercial banks in China. The research conclusions of this paper have positive significance for preventing the risks brought by shadow banking to Chinese commercial banks.
\end{abstract}

\section{Keywords}

Loan Loss Provisions, Shadow Banking, Commercial Bank

\section{Introduction}

With the development and deepening of finance, in order to meet the demand for financial resources for economic development and improve the efficiency of resource allocation in financial markets, shadow banking and institutions have begun to emerge. But the bubble-like expansion has huge risks, especially the shadow banking has eroded the original financial landscape, squeezed the market share of traditional finance, and affected the commercial banks' business behavior and risk control decisions. In this context, analyzing how shadow banking affects commercial banks is of great significance.

The outbreak of the subprime mortgage crisis in the United States has aroused attention from all walks of life to shadow banking, and people generally attribute the crisis to the excessive development and lack of supervision of shadow banking. In October 2012, the "Global Financial Stability Report" issued by the International Monetary Fund (IMF) reminded that China should pay attention to the "shadow banking" problem. The shadow banking risks in China have also caused widespread concern at home and abroad, and their worries have become 
increasingly heated. With the expansion of shadow banking, risks have gradually emerged.

At present, Chinese scholars' research on shadow banking is more focused on the impact of China's shadow banking on the effectiveness of monetary policy and the stability of the financial system. These studies have improved our understanding of issues related to China's shadow banking, but it is worth pointing out that most of the existing studies have studied the impact of shadow banking on the financial system from a macro level, or they have to use theoretical models to analyze the effects of shadow banking and monetary policy. It has rarely dealt with important issues such as how traditional commercial banks deal with shadow banking. This article focuses on whether banks can deal with the risks brought by shadow banking by making loan loss provisions. This article is theoretically innovative. In this context, this article mainly studies the impact of shadow banking on commercial banks' loan loss provisions.

\section{Literature Review and Hypotheses}

\subsection{Literature Review}

The concept of "Shadow Banking" was first proposed by McCulley (2007), executive director of Pacific Investment Management Corporation, and refers to all types of financial institutions that perform similar banking functions outside the commercial banking system and their various financial activities. Since then, the concept has been widely adopted, and there have been many discussions about shadow banking in various circles, but still lack a comprehensive and authoritative precise definition. The Financial Stability Board (FSB, 2011), from a broad perspective, defines shadow banking as a credit intermediary entity and credit intermediary activity that is outside the traditional banking system, and is a credit intermediary system outside the banking supervision system that may cause systemic risks and regulatory arbitrage. China currently adopts the concept of FSB. The "Statement on Strengthening Shadow Banking Issues" issued by the State Council in 2013 pointed out that China's shadow banking mainly includes three types:

1) Credit intermediaries that do not hold financial licenses and are completely unsupervised, including new online financial companies and third-party financial management institutions, etc.

2) Credit intermediaries that do not hold financial licenses and have insufficient supervision, including financing guarantee companies and small loan companies.

3) The institution holds financial licenses, but has insufficient supervision or evades supervision, including money market funds, asset securitization, and some wealth management services.

Research on the economic consequences of shadow banking has focused more on the risk level. Zhao Wei (2013) found that shadow banking weakened the transmission of monetary policy and brought financial instability [1]. Xiaoming 
Lu (2014) pointed out that unlike the US shadow banking, which has expanded its funding sources and reduced financing costs, China's shadow bank has allowed credit funds to repeatedly flow between financial institutions, raising corporate financing costs, and ultimately leading to a decline in corporate profitability and increased risks [2]. Wang et al. (2015) studied the shadow banking activities of non-financial enterprises in China and found that refinancing activities of non-financial enterprises are widespread in China, and that state-owned enterprises are more involved in refinancing activities than private enterprises [3]. Li and Lin (2016) analyzed the capital supervision of shadow banking and believed that the development of shadow banking business can improve the bank's return on capital, but at the same time reduce the stability of the bank [4]. Research by Zhan and Li (2018) pointed out that the development of shadow banking has strengthened the effect of asset price channels, while relatively weakened the effects of credit channels and interest rate channels [5].

The essence of shadow banking is regulatory arbitrage. Although shadow banking has played an active role in promoting resource allocation and improving bank asset liquidity, the current empirical papers focus more on its risks to the financial system. From a macro perspective, shadow banking will weaken the transmission of monetary policy. From a micro perspective, shadow banks promote commercial banks and non-financial enterprises to engage in shadow banking and increase the instability of the financial system.

As the main asset of a commercial bank, the value of loans is affected by multiple impairment risks such as credit risk and interest rate risk. In order to confirm these risks timely and form an early warning and capital buffer mechanism, banks will make provision for impairment losses on loans based on the possible losses caused by these risks, that is, loan loss provisions. The influencing factors of loan loss provisions are often divided into discretionary factors and non-discretionary factors. Discretion factors include profit smoothing, capital management, and signal transmission; non-discretion factors include bank size and tax policies. For example, Curcio and Hasan (2015) found that when the bank's equity capital is low, the bank will overstate the loan loss provisions to make up for its low capital level, and underestimate the loan loss provisions when there is sufficient equity capital, reflecting the banks make provision of loans for capital management purposes [6]. Chen and $\mathrm{Wu}$ (2014) found that China's commercial banks have a behavior of smoothing profits by making provision for loans, but the accounting standards implemented since 2007 have a significant inhibitory effect on this behavior [7]. Norden and Stoian (2014) found that banks using loan loss provisions for profit smoothing can reduce the volatility of their returns, but weaken their risk response capabilities [8]. Dai and Zhang's (2016) research shows that loan loss provisions can effectively deal with the risks of commercial banks. Under the premise that the loan quality of the current period remains unchanged, the more loan loss provisions for commercial banks, the more individual risks and the lower spillover risks in the future, 
and earnings management behavior weakens the risk response capacity of loan loss provisions [9]. Ozili and Outa (2018) found that the mandatory use of international accounting standards by Nigerian banks weakened their incentive to use loan loss provisions for profit smoothing [10].

The research on loan loss provisions for the three major motivations of profit smoothing, capital management, and signal transmission has been comprehensive enough. In addition, research on taxation, accounting systems, and auditing has also been involved. However, loan loss provisions in commercial banks' risk management and control role, rarely explored. This article provides new evidence for the risk response capabilities of loan loss provisions in order to make up for the deficiencies of previous research.

\subsection{Hypotheses}

The development of shadow banking has enabled families to choose high-yield financial products or wealth management products when choosing financial assets for investment, while reducing the amount of general bank savings held. In order to obtain funds, banks must pay higher financing costs. In addition, shadow banking has caused a huge impact on the lending business of commercial banks. Shadow banks such as P2P online lending, microfinance companies, and financial leasing companies compete for borrowers [11]. The rapid development of shadow banking has forced commercial banks seeking to maximize profits to increase their risk-taking levels. In other words, shadow banking has triggered the "price dividend" enjoyed by the traditional financial system, forcing commercial banks to change their management strategies, radicalize their operations, and increase risk-taking. In order to cover higher financing costs, banks need to issue high-yield and high-risk loans. In the fierce banking competition environment, banks also have an incentive to relax the credit business access standards, enabling some high-risk customers to obtain credit, expand high-risk loans credit scale,, which affect the credit risk level of commercial banks [12].

Credit discrimination is a unique phenomenon in China's economic practice. Some large enterprises and state-owned enterprises have lower productivity and profitability, but they can still easily obtain funds from commercial banks; while some small and medium-sized companies cannot obtain bank loans even if they have good investment opportunities, they have to pay high interest to get funds such as private loans. Existing research shows that refinancing activities of non-financial companies are widespread in China, and state-owned enterprises are more involved in refinancing activities than private enterprises [3]. Non-financial companies such as state-owned enterprises, as financial intermediaries, lend funds borrowed cheaply from banks to other companies. From the perspective of the asset side of credit-type shadow banking, their capital flows are mainly small, medium and micro enterprises with low credit ratings and lack of collateral to obtain credit support from commercial banks [13]. This re-lending behavior will increase the degree of information asymmetry between 
the borrower and the borrower. Compared with the situation where the information asymmetry is small, when the degree of information asymmetry between the borrower and the lender is greater, the adverse selection and moral hazard problems induced by the information asymmetry will be more serious, thereby aggravating the loan risk.

In order to cope with fierce competition, commercial banks themselves also engage in shadow banking. Although it is a financial innovation on the surface, it is still essentially a bank loan business. This kind of homogeneous competition will lead to an increase in the risk of the banking system. Once a negative impact is encountered, the bank risk will have a chain reaction among the banks, which will have a serious negative impact on the security of the entire banking system. In China's shadow banking system, in order to evade supervision, funds are repeatedly flowed between financial institutions, resulting in high actual loan interest rates for end-user companies. Therefore, once operational problems occur in investment projects, shadow banking products may generate bad debts. Commercial banks engaging in shadow banking business will dilute the return on total assets and increase the potential risks of commercial banks [14]. Some studies have found that the interest rate of shadow banking can reach more than three times the benchmark interest rate of loans, and some funds flow to high-risk projects such as real estate development, resulting in deterioration of the overall asset quality of banks [15]. Due to the characteristics of shadow banking business with long transaction chains, many counterparties, and complicated legal relationships, commercial banks usually do not directly downgrade risks to non-performing assets when credit risk events occur, but instead transfer them to the table by issuing loans to undertake risky assets. Disposal of credit accounts and eventually evolved into an increase in the rate of non-performing loans. For example, in January 2018, the case of SPD Bank Chengdu Branch issuing loans illegally was disclosed on the official website of the China Banking Regulatory Commission. The credit granted to SPD Bank Chengdu Branch to mining enterprises has a large number of shadow banking businesses such as entrusted loans, outsourced investments, and off-balance sheet investments. In recent years, the steel and coal industry has been in a slump, and the quality of shadow banking assets has declined. The branch has covered risks by "borrowing acquisitions" and issuing loans to shell companies. After the problem was exposed, the above-mentioned business of the branch formed a non-performing loan of 10 billion yuan, which ultimately greatly affected the non-performing loan ratio of the branch.

The loan loss provisions have the function of early warning, which can prompt the users of the report with risk information, thereby helping commercial banks to cope with the risk. Loan loss provisions can effectively deal with commercial bank risks [9]. Facing the risks brought by shadow banking, banks will respond by making provision for loans. Therefore, Hypothesis 1:

H1: Shadow banks have significantly increased the provision for loans. 


\section{Research Method}

\subsection{Sample Selection}

The research sample of this article is the data of Chinese commercial banks from 2008 to 2018. Among them, the relevant data of the commercial bank's data comes from the Bankscope database, the missing values are collected manually by the bank's annual report, the shadow banking data comes from the People's Bank of China and the China National Bureau of Statistics, and the GDP data comes from the National Bureau of Statistics. Because of the incomplete disclosure of annual reports of early unlisted banks, some data were still unavailable. The data processing process in this article is as follows: 1) delete non-bank financial institutions, foreign banks, and three major policy banks, and retain only the data of commercial banks; 2) exclude banks lacking data for less than three consecutive years. Considering that there may be extreme values in the sample data that affect the model estimation results, the sample data is processed at the $1 \%$ level, and the data outside the $1 \%-99 \%$ quantile is reduced to $1 \%$ or $99 \%$. The data processing in this paper uses stata.12 statistical software.

\subsection{Variable Selection and Measurement}

According to the definition of the Financial Stability Board (FSB), shadow banking is a new form of financial innovation that is outside the banking supervision system. In China, shadow banking in a broad sense includes: banking wealth management products, entrusted loans, trust loans, P2P, and various private lending [16] [17]. Since China's public statistics do not have systematic information on the development of shadow banking, overall data on the development of shadow banking is difficult to obtain. In order to obtain data for the sample period, Moody's core shadow banking definition is used here to measure the development level of shadow banking in China, that is, the size of shadow banking $=$ trust loans + entrusted loans + undiscounted bank acceptance bills.

This article uses the ratio of loan provision to total loan amount (LLP) in this period to measure the loan loss provisions of Chinese commercial banks. This article adds the following control variables to the model: 1) Non-discretionary factors: Generally, the non-performing loan ratio (NPL) and loan size (Loan) are used to measure the expected credit risk of bank loans. 2) Discretionary factors: use core capital adequacy ratio (HCAP), total capital adequacy ratio (TCAP), and profit before taxation (EBPT) to analyze managers' capital management and profit smoothing motivations. 3) Others: because different bank characteristics will have different impacts on the bank's operating decisions, and then affect the management's action of loan loss provisions. The bank size and net bad debt write-off rate (NCO) are also selected. Loan provisions are also affected by the macroeconomic growth, so this article will control the growth rate of GDP. The four major banks and 12 national joint-stock banks use the national GDP data, and other banks use the GDP data of the provinces where the banks are located. Table 1 presents the variable definitions used in the regression model. 


\subsection{Model Design}

Based on H1, this paper draws on the research ideas of Ng et al. (2018) to build a model (1). The dependence variable is Loan loss provisions (LLPs) scaled by total loans. The independent variable is Shadow. We control for NPL, Loan, EBPT, HCAP, TCAP, NCO, Size, GDP. According to the theoretical analysis of H1, we predict that the coefficient of Shadow should be significantly positive.

$$
\begin{aligned}
\operatorname{LLP}_{i, t}= & \alpha_{0}+\alpha_{1} \operatorname{Shadow}_{t}+\alpha_{2} \mathrm{NPL}_{i, t}+\alpha_{3} \operatorname{Loan}_{i, t}+\alpha_{3} \mathrm{EBPT}_{i, t}+\alpha_{4} \mathrm{HCAP}_{i, t} \\
& +\alpha_{5} \mathrm{TCAP}_{i, t}+\alpha_{6} \mathrm{NCO}_{i, t}+\alpha_{7} \operatorname{Size}_{i, t}+\alpha_{8} \mathrm{GDP}_{i, t}+\varepsilon
\end{aligned}
$$

\section{Empirical Results and Analysis}

\subsection{Descriptive Statistics}

Descriptive statistics of the main variables are shown in Table 2. The maximum value of loan loss provisions is $2.92 \%$, and the minimum value is $0.11 \%$. In June 2012, the former China Banking Regulatory Commission issued the "Capital Management Measures for Commercial Banks (Trial)", which stipulated that the core capital adequacy ratio of commercial banks must not be lower than $5 \%$ and the total capital adequacy ratio must not be lower than 8\%. From 2008 to 2018,

Table 1. Variable definition.

\begin{tabular}{cc}
\hline Variable name & Explanation \\
\hline LLP & Loan loss provisions (LLPs) scaled by total loans \\
Shadow & The sum of trust loans, entrusted loans and undiscounted bank acceptance bills \\
NPL & Non-performing loans scaled by total loans \\
Loan & Total loans outstanding scaled by total assets \\
TCAP & Core capital adequacy ratio \\
TCAP & Total capital adequacy ratio \\
EBPT & Earnings before provisions and taxes \\
NCO & Net charge-offs scaled by total assets \\
Size & Natural logarithm of total assets \\
GDP & Provinces' GDP growth rate
\end{tabular}

Table 2. Descriptive statistics.

\begin{tabular}{cccccc}
\hline Variable name & mean & $\mathrm{p} 50$ & $\min$ & $\max$ & $\mathrm{sd}$ \\
\hline LLP & 1.05 & 0.94 & 0.11 & 2.92 & 0.6 \\
NPL & 1.44 & 1.35 & 0.17 & 4.66 & 0.75 \\
Loan & 0.04 & 0.04 & 0.02 & 0.06 & 0.01 \\
EBPT & $43,146.31$ & 5372.05 & 854.00 & $640,000.00$ & $110,000.00$ \\
HCAP & 10.63 & 10.4 & 6.91 & 17.41 & 1.78 \\
TCAP & 12.93 & 12.68 & 9.69 & 18.64 & 1.63 \\
Size & 19.59 & 19.18 & 17.25 & 23.77 & 1.55 \\
\hline
\end{tabular}


the minimum capital adequacy ratio of the sample banks was $6.91 \%$ and the minimum capital adequacy ratio was $9.69 \%$, all meeting the capital requirements. In addition, the average (median) of the profit before provision EBTP was 43,146.31 (5372.05), and the average (median) of non-performing loans (NPL) was $1.44 \%(1.35 \%)$.

\subsection{Regression Results}

Regression results can be seen from Table 3. From the regression results, it can be found that the Shadow Bank coefficient is 0.0102 , which is significantly positive at the level of $5 \%$, which is consistent with expectations, indicating that when the size of the shadow banking increases, commercial bank accountants provide more loan loss provisions. At the same time, it was found that the loan loss provisions (LLP) and the non-performing loan ratio (NPL) were significantly negatively correlated at the level of $1 \%$. However, the relationship between loan provision (LLP), core capital adequacy ratio (HCAP), and capital adequacy ratio (TCAP) is not significant, indicating that banks have no motivation for capital management. The NCO coefficient is significantly positive, indicating that the larger the bank's net charge-offs, the larger the loan loss provisions. The coefficient of GDP is not significant, indicating that in the data analysis of this article, the periodic effect of loan loss provisions has not been reflected. Therefore, the test results of Model 1 verify $\mathrm{H} 1$ in this paper, that is, the commercial bank loan provision is significantly positively related to shadow banking.

\section{Conclusions}

This paper uses the data of China's commercial banks from 2008 to 2018 to

Table 3. Hypothesis (1) regression results.

\begin{tabular}{cc}
\hline Variables & Explanation \\
Shadow & $0.0102^{\star *}(0.00450)$ \\
NPL & $0.187^{\star * *}(0.0397)$ \\
Loan & $-12.73^{* * *}(3.039)$ \\
EBPT & $-0.0000(0.0000)$ \\
HCAP & $-0.0137(0.0240)$ \\
TCAP & $0.00857(0.0249)$ \\
NCO & $1275^{\star * *}(120.8)$ \\
Size & $0.000267(0.0212)$ \\
GDP & $0.00598(0.0155)$ \\
Constant & $0.851(0.616)$ \\
Observations & 676 \\
R-squared & 0.504 \\
\hline
\end{tabular}

Robust standard errors in parentheses. ${ }^{* *} \mathrm{p}<0.01,{ }^{* *} \mathrm{p}<0.05,{ }^{*} \mathrm{p}<0.1$. 
establish a regression model for empirical research and finds that shadow banking and China's commercial banks' loan loss provisions have a significant positive correlation. It shows that China's commercial banks respond to the risks brought by shadow banking by making loan loss provisions.

This article has positive significance for preventing financial risks brought by shadow banking. Loan loss provisions are both a line of defense for commercial banks in responding to non-performing loans and a tool for coping with risks. Commercial banks need to make reasonable provision for loans to deal with the financial risks caused by shadow banking. At the same time, the government should further improve its regulatory policies.

\section{Conflicts of Interest}

The author declares no conflicts of interest regarding the publication of this paper.

\section{References}

[1] Zhao, W. (2013) Research on the Impact of "Shadow Banking" on Credit Rationing of Commercial Banks. Economic Issues, No. 5, 45-48.

[2] Lu, X.M. (2014) Comparative Analysis and Enlightenment of China-US Shadow Banking System. International Finance Research, No. 1, 55-63.

[3] Wang, Y.X., Li, Z.H., Li, C. and Du, J.L. (2015) Identifying Shadow Banking Activities of Chinese Non-Financial Companies-Evidence from Consolidated Balance Sheets. Management World, No. 15, 24-40.

[4] Li, X. and Lin J. (2016) Shadow-Banking Entrusted Loan Management, Deposit Insurance Premium and Capital Regulation. International Review of Economics \& Finance, 41, 98-109. https://doi.org/10.1016/j.iref.2015.09.003

[5] Zhan, M.H. and Li, H. (2018) Has the Process of Financial Marketization Changed the Relative Effects of Different Transmission Channels of China's Monetary Policy? Financial Research, No. 5, 20-36.

[6] Curcio, D. and Hasan, I. (2015) Earnings and Capital Management and Signaling: The Use of Loan Loss Provisions by European Banks. The European Journal of Finance, 21, 26-50. https://doi.org/10.1080/1351847X.2012.762408

[7] Chen, W.L. and Wu, X. (2014) China's Commercial Banks' Loan Loss Provisions and Profit Smoothing: The Impact of New Accounting Standards. Audit Research, No. 1, 105-112.

[8] Norden, L. and Stoian, A. (2014) Bank Earnings Management through Loan Loss Provisions: A Double-Edged Sword? De Nederlandsche Bank Working Paper. https://doi.org/10.2139/ssrn.2369798

[9] Dai, D.M. and Zhang, S.S. (2016) Loan Loss Provisions, Earnings Management and Risk Management of Commercial Banks. Accounting Research, No. 8, 25-33 + 96.

[10] Ozili, P.K. and Outa, E.R. (2017) Bank Loan Loss Provisions Research: A Review. Borsa Istanbul Review, 17, 144-163. https://doi.org/10.1016/j.bir.2017.05.001

[11] Buchak, G., Matvos, G., Piskorski, T. and Seru, A. (2017) Fintech, Regulatory Arbitrage, and the Rise of Shadow Banks. Journal of Financial Economics, 130, 453-483. https://doi.org/10.1016/j.jfineco.2018.03.011

[12] Ahn, J.H. and Breton, R. (2014) Securitization, Competition and Monitoring. Jour- 
nal of Banking and Finance, 40, 195-210.

https://doi.org/10.1016/j.jbankfin.2013.11.023

[13] Fang, X.M. and Quan, W. (2017) Credit Cycle Banking Procyclical Behavior Test. Financial Research, No. 6, 64-80.

[14] Zhu, J.G., Hu, S.Y. and Lu, Z.F. (2016) The Influencing Factors and Economic Consequences of Commercial Banks' Engagement in Shadow Banking-An Empirical Study Based on the Shadow Finance System's Capital Finance. Financial Research, No. 1, 66-82.

[15] Chen, S.Y., Wang, L. and Yang, L. (2018) The Impact of Shadow Banking Activities on Banking Efficiency: Evidence from Chinese Commercial Banks. Wuhan University Journal (Philosophy and Social Sciences Edition), 71, 103-118.

[16] Ba, S.S. (2013) Objectively Evaluate Shadow Banking from the Perspective of Financial Structure Evolution. Economic Aspect, No. 4, 27-30.

[17] Ng, J., Saffar, W. and Zhang, J.J. (2018) Policy Uncertainty and Loan Loss Provisions in the Banking Industry. Working Papers. 